\title{
A Review on the Formation of Carcinogenic/Mutagenic Heterocyclic Aromatic Amines
}

\author{
Mevlüde Kizili*, Fatih $\mathrm{Oz}^{2}$ and $\mathrm{H}$ Tanju Besler ${ }^{1}$ \\ ${ }^{1}$ Department of Nutrition and Dietetics, Faculty of Health Sciences, Hacettepe University, 06100 Ankara, Turkey \\ ${ }^{2}$ Department of Food Engineering, Faculty of Agriculture, Atatürk University, 25240 Erzurum, Turkey
}

\begin{abstract}
Mutagenic and/or carcinogenic heterocyclic aromatic amines (HCAs) have been found in meat and fish cooked at temperatures over $150^{\circ} \mathrm{C}$. To date, more than $25 \mathrm{HCAs}$ have been isolated and identified in cooked meat and meat products as potent mutagens in the Ames/Salmonella test. HCAs are potent mutagens at ng/g levels in cooked foods and play an important role in the etiology of human cancer. Major precursors of HCAs are creatine and/or creatinine, amino acids and reducing sugars. IQ-type HCAs are formed by heat induced non enzymatic browning known as Maillard reaction which involves creati(ni)ne, amino acid and sugars whereas amino-carbolines are mainly formed by pyrolysis of amino acids and proteins at higher temperatures above $300^{\circ} \mathrm{C}$. Concentrations and variety of HCAs can be dependent on many factors such as precursor level, meat type, cooking method, cooking duration, $\mathrm{pH}$ and water activity, heat and mass transfer, lipid level, lipid oxidation and antioxidants. Due to better understanding, formation of HCAs has been studied both in model systems and cooked foods and this review gives an overview of the studies on the formation of carcinogenic and/or mutagenic HCAs.
\end{abstract}

\section{Introduction}

Human epidemiologic and animal studies have shown that diet plays an important role in cancer development [1,2]. It has been reported that one third of human cancers are related to foods. Heterocyclic aromatic amines (HCAs) are potent mutagens at $\mathrm{ng} / \mathrm{g}$ levels in cooked foods and play an important role in the etiology of human cancer [3]. The International Agency for Research on Cancer (IARC) regards some of the HCAs as possible human carcinogens (2-amino-3,4-dimethyl-imidazo[4,5-f] quinoline (MeIQ), 2-amino3,8-dimethyl-imidazo[4,5-f]quinoxaline (MeIQx) and 2-amino-1methyl-6-phenylimidazo[4,5-b]pyridine (PhIP), class 2B) and one as a probable human carcinogens (2-amino-3-methylimidazo[4,5- $f$ ] quinoline (IQ), class 2A)[4]. The mutagenicity of HCAs in meat has been assessed by using the microsom test of Ames/Salmonella [5] and HCAs are over 100 fold more mutagenic than aflatoxin B1 and over 2,000-fold more mutagenic than benzo[a]pyrene [6].

Mutagenic and/or carcinogenic HCAs have been found in meat and fish cooked at temperatures over $150^{\circ} \mathrm{C}$ and first discovered by Japanese scientist Sugimura in 1977 [7]. To date, more than 25 HCAs have been isolated and identified in cooked meat and meat products [8]. HCAs can be classified into two main groups called IQ-type HCAs or aminoimidazoazaarenes and non IQ-type HCAs or aminocarbolines. IQ-type HCAs are formed by heat induced non enzymatic browning known as Maillard reaction which involves creati(ni)ne, amino acid and sugars whereas amino-carbolines are mainly formed by pyrolysis of amino acids and proteins at higher temperatures above $300^{\circ} \mathrm{C}$ [9-11]. Their formation is highly dependent on various factors such as cooking temperature, cooking method, cooking time, type of meat, fat, and moisture content $[11,12], \mathrm{pH}$, sugar, free amino acid and creatinine content of meat [13]. In addition heat and mass transfer, lipid oxidation and antioxidants have effect on concentration of HCAs [13-15].

Due to better understanding, the formation of HCAs has been studied both in model systems and cooked foods. This review gives an overview of the studies on the formation of carcinogenic and/or mutagenic HCAs.

\section{Structures and Formation of HCAs}

HCAs have two major classes: aminoimidazoazoarenes (AIAs) and aminocarbolines [14]. The AIAs are the most important class in cooked foods. They have an imidazo group linked to a quinoline, a quinoxaline or a pyridine [16]. AIAs are also called imidazoquinoline (IQ)-type compounds or thermic HCAs and generated from the reaction of free amino acids creatine, creatinine and hexoses during cooking of foods at conventional cooking temperatures $\left(150-300^{\circ} \mathrm{C}\right)$. The other amines, aminocarbolines, are formed at temperatures above $300^{\circ} \mathrm{C}$ [17]. Aminocarbolines are also called non-IQ-type compounds or pyrolytic HCAs. They are formed in the pyrolytic reaction of amino acids and proteins at higher temperatures [10]. Some of these carbolines contain a 2-aminopyridine moiety as a common structure. Harman and norharman are not mutagenic but are co-mutagenic since they enhance the genotoxicity of mutagenic HCAs. These compounds are included among the aminocarbolines, also sometimes grouped as polar and nonpolar according to their chemical behavior [18]. Table 1 (included as supplementary data) shows the classification of HCAs.

\section{Precursors and factors of HCAs formation}

Several studies reported that major precursors of HCAs creatine and/or creatinine, amino acids and reducing sugars [20,21]. But some studies have shown that sugar is not obligatory for the formation of AIAs [22,23]. Adding small amount of reducing sugar to model systems

*Corresponding author: Kizil M, Department of Nutrition and Dietetics Faculty of Health Sciences, Hacettepe University, 06100 Ankara, Turkey, Tel: +90.312.3051094; Fax: +90.312.3091310; E-mail: mkizil@hacettepe.edu.tr

Received August 25, 2011; Accepted September 28, 2011; Published September 30, 2011

Citation: Kizil M, Oz F, Besler HT (2011) A Review on the Formation of Carcinogenic/Mutagenic Heterocyclic Aromatic Amines. J Food Process Techno 2:120. doi:10.4172/2157-7110.1000120

Copyright: (c) 2011 Kizil M, et al. This is an open-access article distributed under the terms of the Creative Commons Attribution License, which permits unrestricted use, distribution, and reproduction in any medium, provided the original author and source are credited. 
and meat before cooking resulted in increased production of mutagens [24]. On the other hand, the addition of glucose in amounts greater than half the molar concentration of amino acids and creatine has been shown to reduce the formation of cooked food mutagens in model systems [24,25]. Creatine, free amino acids and hexoses, present in raw meat, were suggested the precursors of IQ-compounds. Creatine was postulated to form the 2-amino-3- methylimidazo (2-aminoimidazo) moiety of AIAs by cyclization and water elimination, a reaction that takes place spontaneously when the temperature is raised above $100^{\circ} \mathrm{C}$. This part of the molecule is a common moiety of all IQ- compounds and is also responsible for the mutagenicity of IQ substances. Without this part, and especially its 2 -amino group, the mutagenicity becomes almost negligible $[11,26]$.

The remaining parts of IQ-compounds are assumed to arise from Strecker degradation products, such as pyridines or pyrazines, formed in the Maillard reaction between hexoses and amino acids. Aldol condensation is believed to link the two parts together via an aldehyde [12]. Figure 1 shows suggested pathway for the formation of IQ-type and IQx-type compounds.

Muscle meats contain creatine and creatinine, which can react with free amino acids and sugars during cooking [28]. Creatine is therefore basically responsible for the mutagenic activity of meat [29]. During cooking of meat or fish, creatine is converted to creatinine, which then forms the imidazo part of AIAs [26]. Higher cooking temperatures lead to a more rapid decrease in creatine and increase in creatinine. In addition, creatinine has been shown to produce about $50 \%$ more mutagenicity than creatine when heated with certain amino acids and glucose in model systems [10,24]. Mutagen production is strongly dependent on the amount of moisture initially present in the meat above approximately $40 \%$ [30]. Water-soluble mutagenic agent precursors migrate with water toward the surface of food [29].

Imidazoquinoxaline type HCAs are formed in the model mixture consist of glucose, glycine and creatinine through free radical Maillard intermediates, a pyrazine cation radical and carbon-centered radicals [31-34]. In the initial stage of Maillard reaction of glucose with glycine, both pyrazine cation radical and cation centered radicals are generated and in the presence of phenolic antioxidants they are scavenged [31]. In the model mixture composed of glucose, glycine and creatinine has shown that epigallocatechin gallate and flavonoids prevent the HCAs formation [35]. Moreover, iron is a well-known catalyst of lipid oxidation at lower temperatures and Johansson and Jägerstad [33] reported that the addition of iron $\left(\mathrm{Fe}^{2+}\right.$ and $\left.\mathrm{Fe}^{3+}\right)$ to creatine, glycine, glucose model system, increased the formation of IQx, MeIQx and DiMeIQx approximately two fold.

Several studies have reported that natural and synthetic antioxidants decreased mutagenic activity or inhibited the formation of HCAs. Spices are source of natural antioxidants and their effects on the formation of HCAs were investigated. Rosemary oleoresin [35], rosemary extract added to virgin olive oil [36], oleoresin or grape seed extract [37], spice-containing marinades [38], adding red and black pepper $[39,40]$ can be effective inhibitors of HCAs formation. Marinating is another method can decrease the concentration of HCAs and several studies have shown reduced effect of marinated chicken before grilling on concentration of HCAs [41,42].

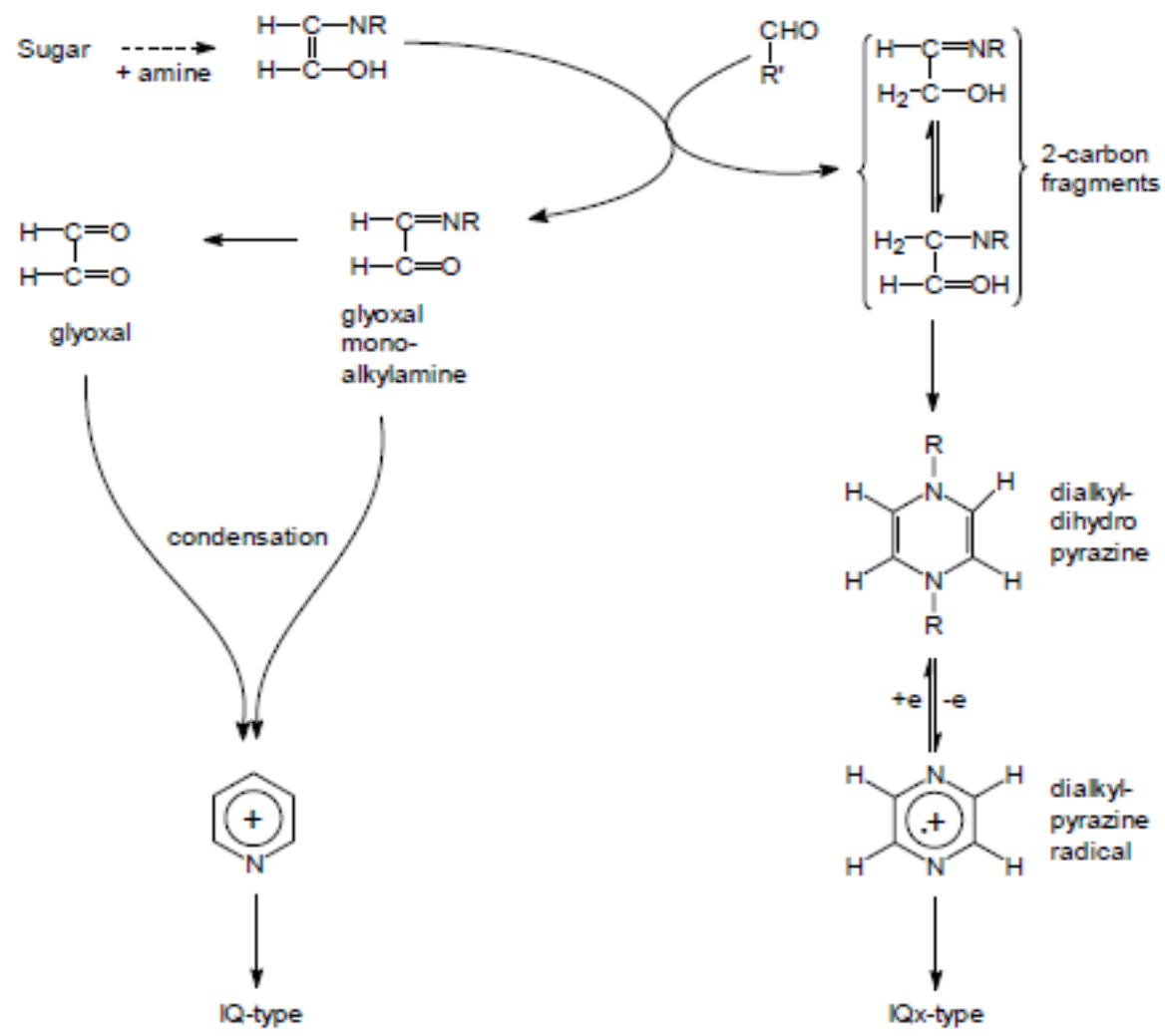

Figure 1: Suggested pathway for the formation of IQ-type and IQx-type compounds [27]. 
It was shown that phenylalanine, creatinine and glucose were probable precursors of PhIP [27]. PhIP may also be produced from creatine heated together with leucine, isoleucine and tyrosine. Glucose seems not to be a necessary precursor using dry heating conditions [34]. But glucose have a considerable influence, either enhancing or inhibiting depending on its concentration, on the formation of PhIP from phenylalanine and creatine in both a liquid model system and during dry heating [24]. It has been reported that erythrose is the most active in the formation of PhIP, when phenylalanine and creatinine dissolved in water is heated at temperatures of 37 and $60^{\circ} \mathrm{C}$. The other carbohydrates namely arabinose, ribose, glucose and galactose are not as active [43].

Although mutagenic activity was first reported in proteinaceous foods, no mutagenic activity was detected when proteins instead of amino acids were reflux-boiled in a model system [12]. Studies with model systems showed that amino acids or short-chain peptides were absolutely necessary for the formation of AIAs [45]. Knize and others [46]. reported that different amino acids were precursors for one mutagenic compound. Refluxing carnosine (b-alanine + L-histidine) with creatinine and glucose at $130^{\circ} \mathrm{C}$ for $2 \mathrm{~h}$ produced similar mutagenic activity to many other amino acids. This result showed that a dipeptide can contribute to the mutagenic activity. However, the highest mutagenic activity was reported for threonine, followed by glycine and lysine [10]. The presence of sugars is necessary for the formation of mutagenic activity in meat. Very low mutagenic was detected in the crust of meat after beef patties (with low glucose) were fried. The patties lacked the meat aroma and also a brown color was not developed in the crust as a result of the Maillard reaction. However, the mutagenic activity increased twofold to threefold when a small amount of glucose was added to the meat before frying [10].

Dolara and others [47] reported that the external surface of cooked meat show greater levels of mutagenic activity than the inner parts. It has been reported that cooking temperature and duration have a much greater influence on the formation of HCAs than the present of precursors (creatine, sugars, and free amino acids) or the amount of water of food $[48,49]$. Cooking temperature has been reported to be the most important parameter [34,50]. The concentrations of AIAs generally increased with cooking temperature [34,50]. In aqueous model system consisted of creatine, glucose and a blend of amino acids were heated at $150-225^{\circ} \mathrm{C}$ for 0.5 to $120 \mathrm{~min}$ in order to investigate the relation between temperature and time in the formation of HCAs led to rapid formation of IQx, MeIQx, 4,8DiMeIQx and PhIP but not IQ or MeIQ [50]. Most model system studies have been performed at $125-300^{\circ} \mathrm{C}$. In liquid model systems for the formation of PhIP from phenylalanine, creatinine and glucose, the concentration of PhIP was increase when the temperature was increased from 180 to 225 C [51]. In meat or model systems, mutagenic activity or the formation of AIAs increased with processing time at $150-170^{\circ} \mathrm{C}$. However, the concentrations of HCAs increased during the initial period of processing and then decreased at higher temperatures $\left(190-250^{\circ} \mathrm{C}\right)$ $[24,52]$. Formation of HCAs can be minimized if the cooking temperature is kept low and constant. In domestic cooking, temperature is generally below $200^{\circ} \mathrm{C}$. Increase in cooking time and temperature lead to increase the amounts of HCAs and PhIP level is higher at higher cooking temperatures and in longer cooking time [12,50,53,54]. Bjeldanes and others $[30,55]$ reported that mutagenic activity in grilled meat increased rapidly during the initial $10 \mathrm{~min}$ and then decreased. They declared that the decreasing might be due to the formation of an obvious, distinct crust on the meats, which appears to inhibit further heat transfer to the interior of the meat. In addition coating foods with breadcrumbs before frying may reduce the formation of HCAs because of the insulating effect of coating [50].

Cooking method is another factor for the HCAs formation [56]. Investigations of various cooking methods have shown pan-frying and grilling/ barbecuing to generally yield higher levels of HAAs than oven roasting, deep-fat frying, boiling or microwaving [57,58]. High concentrations of HAAs are formed during pan-frying, especially at temperatures, above $225^{\circ} \mathrm{C}$ [21]. Similarly Oz and others [59] reported that the highest total HCAs amount found in pan fried fish and no HCAs detected in fish fillet cooked with microwave or hot plate. Microwave, oven and hot plate cooking to all various doneness degrees in beef samples did not cause HCAs formation whereas barbecuing and pan frying led to HCAs formation in beef samples [60].The heat transfer by air may be the explanation of the lower amounts of HAAs formed during oven cooking. In oven cooking also less mutagenic activity was formed in the presence of steam which affected the heat transport and decreased the surface temperature of products [34]. Oz et al. [61] found that microwaved cooked chicken had the lowest total HCAs amount and emphasized microwave pretreatment instead of direct microwave cooking. Microwave pretreatment of meat before frying decreases HCAs formation due to loss of HCAs precursors with the meat juice [28].

The lipid content of meat is also important for the formation of mutagenic activity in crust. However, the role played by lipids is not clear in the development of mutagenic activity. Most authors agree that there is an optimum lipid level for maximum formation of HCAs; in the case of grounded meat, this level is between $10 \%$ and 20\% [44]. Using added fats (butter, margarine or oils) in cooking dramatically increased the amounts of mutagenic compounds at above $200^{\circ} \mathrm{C}$ [62]. This also indicates that lipids are effective heat transfer agents.

\section{Conclusion}

HCAs are potent mutagens and/or carcinogens at $\mathrm{ng} / \mathrm{g}$ levels in cooked foods and play an important role in the etiology of human cancer. Their formation is highly dependent on various factors such as cooking temperature, cooking method, cooking time, type of meat, fat, moisture content, $\mathrm{pH}$, sugar, free amino acid and creatinine content of meat. In addition, heat and mass transfer, lipid oxidation and antioxidants have effect on concentration of HCAs. After evaluations based on high dose, long term animal studies and in vitro and in vivo genotoxicity tests IARC concluded that several HCAs present in cooked foods are possibly (2B) and probably (2A) carcinogenic to humans. But there is insufficient scientific evidence that these toxicants really cause human cancer. There is no general agreement on the role of HCAs regarding human health. However the authorities of Western countries recommend minimizing their formation in our diet.

\section{References}

1. Goldman R, Shields PG (2003) Food mutagens. J Nutr 133: 965S-973S

2. Kulp KS, Fortson SL, Knize MG, Felton JS (2003) An in vitro model systems to predict the bioaccessibility of heterocyclic amines from a cooked meat matrix. Food and Chem Toxicol 41: 1701-1710.

3. Sugımura T (2002) Food and cancer. Toxicology 182: 17-21.

4. International Agency for Research on Cancer (1993) IARC monographs on the evaluation of carcinogenic risks to humans. In Some Natural Occurring Substances: Food Items and Constituents. Heterocyclic Amines andMycotoxins, International Agency for Research on Cancer, Lyon 56: 163-242. 
Citation: Kizil M, Oz F, Besler HT (2011) A Review on the Formation of Carcinogenic/Mutagenic Heterocyclic Aromatic Amines. J Food Process Technol 2:120. doi:10.4172/2157-7110.1000120

Page 4 of 5

5. Knize MG, Sinha R, Rothman N, Brown ED, Salmon CP, et al. (1995) Heterocyclic amine content in fast-food meat products. Food Chem Toxicol 33: 545-551.

6. Stavric B (1994) Biological significance of trace levels of mutagenic heterocyclic aromatic amines in human diet: A critical review. Food Chem Toxicol 32: 977994

7. Nagao M, Honda M, Seino Y, Yahagi T, Sugimura T (1977) Mutagenicities of smoked condensates and the charred surface of fish and meat. Cancer Lett 2 221-226.

8. Sanz AM, Ayala JH, González V, Afonso AM (2008a) Analytical methods applied to the determination of heterocyclic aromatic amines in foods. J Chromatogr B Analyt Technol Biomed Life Sci 862: 15-42.

9. Busquets R, Bordas M, Toribio F, Puignou L, Galceran MT (2004) Occurrence of heterocyclic amines in several home-cooked meat dishes of the Spanish diet. J Chromatogr B Analyt Technol Biomed Life Sci 802: 79-86.

10. Jagerstad M, Laser Reutersward A, Olsson R, Grivas S, Nyhammar T (1983) Creatin(ine) andMaillard reaction products as precursors of mutagenic compounds: Effects of various amino acids. Food Chem 12: 255-264.

11. Sugımura T, Adamson RH (2000) Introduction. In Food Borne Carcinogens, (M. Nagao and T. Sugimura, eds.) pp. 1-5, JohnWiley \& Sons Ltd., Baffins Lane, Chichester,West Sussex P019 1UD, England.

12. Minako Nagao, Takashi Sugimura (1995) Factors affecting the formation and yield of heterocyclic amines. In Heterocyclic Amines in Cooked Foods: Possible Human Carcinogens, (R.H. Adamson, ed.) pp. 9-19, Princeton Scientific Publishing Co., Princeton, NJ.

13. Pais P, Salmon CP, Knize MG, Felton JS (1999) Formation of mutagenic/ carcinogenic heterocyclic amines in dry-heated model systems, meats, and meat drippings. J Agric Food Chem 47: 1098-1108.

14. Jagerstad M, Skog K, Arvidsson P, Solyakov A (1998) Chemistry, formation and occurrence of genotoxic heterocyclic amines identified in model systems and cooked foods. Z Lebensm-Unters-Forsch A 207: 419-427.

15. Oz F, Kaban G, Kaya M (2007) Effects of cooking methods on the formation of heterocyclic aromatic amines of two different species of trout. Food Chem 104 $67-72$

16. Johansson M, Jägerstad M (1993) Influence of oxidized deep-frying fat and iron on the formation of food mutagens in amodel system. Food Chem Toxicol 31 971-979.

17. Torıbıo F, Moyano E, Puıgnou L, Galceran, MT (2002) Ion-trap tandem mass spectrometry for the determination of heterocyclic amines in food. J Chromatogr A 948: 267-281

18. Fay LB, Alı S, Gross GA (1997) Determination of heterocyclic aromatic amines in food products: Automation of the sample preparationmethod prior to HPLC and HPLC-MS quantification. Mutat Res 376: 29-35.

19. Sanz-Alaejos MS, PınoV, Afonso AM (2008) Metabolism and toxicology of heterocyclic aromatic amines when consumed in diet: Influence of the genetic susceptibility to develop human cancer. A review. Food Res Int 41: 327-340.

20. Knıze, MG, Dolbeare FA, Carroll KL,Moore DH, Felton JS (1994) Effect of cooking time and temperature on the heterocyclic amine content of fried beef patties. Food Chem Toxicol 32: 595-603.

21. Chiu CP, Yang DY, Chen BH (1998) Formation of heterocyclic amines in cooked chicken legs. J Food Prot 61: 712-719.

22. Övervık E, Kleman M, Berg I, Gustafsson JÅ (1989) Influence of creatine amino acids and water on the formation of themutagenic heterocyclic amines found in cooked meat. Carcinogenesis 10: 2293-2301.

23. Felton JS, Knıze MG (1991) Occurrence, identification and bacterialmutagenicity of heterocyclic amines in cooked food.Mutat Res 259: 205-217.

24. Skog K, Jägerstad M (1990) Effects of monosaccharides and disaccharides on the formation of foodmutagens in model systems.Mutat Res 230: 263-272.

25. Jackson LS, Hargraves WA (1995) Effects of time and temperature on the formation of MelQx and DiMelQx in a model systemcontaining threonine, glucose, and creatine. J Agric Food Chem 43: 1678-1684.

26. Laser-Reuterswärd A, Skog K, Jägerstad M (1987) Effects of creatine and creatinine content on the mutagenic activity of meat extracts, bouillons and gravies from different sources. Food Chem Toxicol 25: 747-754.
27. Murkovic M (2004) Formation of heterocyclic aromatic amines in mode systems. J Chromatogr B Analyt Technol Biomed Life Sci B 802: 3-10.

28. Felton JS, Fultz E, Dolbeare FA, Knıze MG (1994) Reduction of heterocyclic aromatic amine mutagens/carcinogens in fried beef patties by microwave pretreatment. Food Chem Toxicol 32: 897-903.

29. Jägerstad M, Skog K, Grıvas S, Olsson K (1991) Formation of heterocyclic amines using model systems. Mutat Res 259: 219-233.

30. Bjeldanes LF, Morrıs MM, Tımourıan H, Hatch FT (1983) Effects of mea composition and cooking conditions onmutagen formation in fried ground beef J Agric Food Chem 31: 18-21.

31. Kato T, Harashıma T, Morıaya N, Kıkugawa K, Hıramoto K (1996) Formation of the mutagenic/carcinogenic imidazoquinoxaline type heterocyclic amines through unstable free radical Maillard intermediates and its inhibition by phenolic antioxidants. Carcinogenesis 17: 2469-2476.

32. Mılıć BL, Djılas SM, Canadanovıcâ-Brunet JM (1993) Synthesis of some heterocyclic aminoimidazoazarenes. Food Chemistry 46: 273-276.

33. Johansson MAE, Jägerstad M (1996) Influence of pro- and antioxidants on the formation of mutagenic-carcinogenic heterocyclic amines in amodel system. Food Chem 56: 69-75.

34. Skog KI, Johansson MAE, Jägerstad M (1998) Carcinogenic heterocyclic amines in model systems and cooked foods: A review on formation, occurrence and intake. Food Chem Toxicol 36: 879-896.

35. Ogurı A, Suda M, Totsuka Y, Sugımura T, Wakabayashı K (1998) Inhibitory effects of antioxidants on formation of heterocyclic amines. Mutat Res 402 : 237-245.

36. Balogh Z, Gray JI, Gomaa EA, Booren AM (2000) Formation and inhibition of heterocyclic aromatic amines in fried ground beef patties. Food Chem Toxico 38: 395-401.

37. Persson E, Grazıanı G, Ferracane R, Foglıano V, Skog K (2003) Influence of antioxidants in virgin olive oil on the formation of heterocyclic amines in fried beefburgers. Food Chem Toxicol 41: 1587-1597.

38. Ahn J, Grun IU (2006) Heterocyclic amines: 2. Inhibitory effects of natura extracts on the formation of polar and nonpolar heterocyclic amines in cooked beef. Journal of Food Science 70: 263-268.

39. Smıth JS, Amerı F, Gadgıl P (2008) Effect of marinades on the formation of heterocyclic amines in grilled beef steaks. Journal of Food Science 73: 100 105

40. Oz F, Kaya M (2011a) The inhibitory effect of red pepper on heterocyclic aromatic amines in fried beef Longissimus dorsi muscle. J Food Process Pres doi:10.1111/j.1745-4549. 2011.00532.x.

41. Oz F, Kaya M (2011b) The inhibitory effect of black pepper on formation of heterocyclic aromatic amines in high-fat meatball. Food Control 22: 596-600.

42. Tıkkanen LM, Latva-Kala KJ, Heınıè R-L (1996) Effect of commercia marinades on the mutagenic ac- tivity, sensory quality and amount of heterocyclic amines in chicken grilled under different conditions. Food Chem Toxicol 34: 725-730.

43. Salmon CP, Knıze MG, Felton JS (1997) Effects of marination on the of heterocyclic amine carcinogen formation in grilled chicken. Food Chem Toxicol 35: $433-441$

44. Manabe S, Kurıhara N, Shıbutanı T, Wada O, Uekı A,et al.(1993) Nucleic acids induce the for-mation of a carcinogen, 2-amino-1-methyl-6-phenylimidazo[4,5-b] pyridine (PhIP) in a model system. Carcinogenesis 14: 903-906.

45. Robbana-Barnat S, Rabache M, Rıalland E, Fradın J (1996) Heterocyclic amines: Occurrence and prevention in cooked food. Environ Health Perspect 104: $280-288$

46. Knıze MG, Salmon CP, Hopmans EC, Felton JS (1997) Analysis of foods for heterocyclic aromatic amine carcinogens by solid-phase extraction and highperformance liquid chromatography. J Chromatogr A 763: 179-185.

47. Dolara P, Commoner B,VIthayatgıl A, Cuca G, Tuley E, et al.(1979) The effect of temperature on the formation of mutagens in heated beef stock and cooked ground beef. Mutat. Res. 60: 231-237.

48. Knıze MG, Salmon CP,Mehta SS, Felton JS (1997b) Analysis of cooked muscle meats for heterocyclic aromatic amine carcinogens. Mutat Res 376: 129-134. 
Citation: Kizil M, Oz F, Besler HT (2011) A Review on the Formation of Carcinogenic/Mutagenic Heterocyclic Aromatic Amines. J Food Process Technol 2:120. doi:10.4172/2157-7110.1000120

Page 5 of 5

49. Lan $\mathrm{CM}$, Kao TH, Chen $\mathrm{BH}$ (2004) Effects of heating time and antioxidants on the formation of heterocyclic amines in marinated foods. J Chromatogr B Analyt Technol Biomed Life Sci B 802: 27-37.

50. Skog K, Augustsson K, Steıneck G, Stenberg M, Jägerstad M (1997) Pola and non-polar heterocyclic amines in cooked fish and meat products and their corresponding pan residues. Food Chem Toxicol 35: 555-565.

51. Arvidsson P, Van Boekel MAJS, Skog K, Jagerstad M (1997) Kinetics of formation of polar heterocyclic amines in a meat model system. Journal of Food Science 62: 911-916.

52. Skog K, Jägerstad M (1991) Effects of glucose on the formation of PhIP in a model system. Carcinogenesis 12: 2297-2300.

53. Gross GA, Gruter A (1992) Quantitation of mutagenic/carcinogenic heterocyclic aromatic amines in food products. J Chromatogr 592: 271-278.

54. Johansson M, Fredholm L, Bjerna I, Jagerstad M (1995) Infuence of frying fat on the formation of heterocyclic amines in fried beefburgers and pan residues. Food and Chemical Toxicology 33: 993-1004.

55. Bjeldanes LF, Morris MM, Felton JS, Healy S, Stuermer D, et al.(1982) Mutagens from the cooking of food. II. Survey by Ames/Salmonella test of mutagen formation in the majör protein-rich foods of the American diet. Food Chem Toxicol 20: 357-363.
56. Oz F, Kaya M (2011c) Heterocyclic aromatic amines in meat. J Food Process Pres doi:10.1111/j.1745-4549. 2011.00524.

57. Sınha R, Rothman N, Brown ED, Salmon CP, Knıze MG,et al. (1995) High concentrations of the carcinogen 2-amino-1-methyl-6-phenylimidazo[4,5-b] pyridine (PhIP) occur in chicken but are dependent on the cooking method. Cancer Research 55: 4516-4519.

58. Sınha R, Rothman N, Salmon CP, Knıze MG, Brown ED, et al. (1998) Heterocyclic amine content in beef cooked by different methods to varying degrees of doneness and gravymade frommeat drippings. Food Chem Toxico 36: 279-287.

59. Oz F, Kaban G, Kaya M (2010) Effects of cooking techniques and levels on the formation of heterocyclic aromatic amines in chicken and fish. J AnimVet Adv 9: 1259-1264.

60. Oz F, Kaban G, Kaya M (2010b) Heterocyclic aromatic amine contents of beef and lamb chops cooked by different methods to varying levels. J Anim Vet Adv 9: $1436-1440$.

61. Oz F, Kaban G, Kaya M (2010) Effects of cooking methods and levels on formation of heterocyclic amines in chicken and fish with Oasis extraction method. Food Science and Technology 43: 1345-1350.

62. Nılsson L, Övervık E, Fredholm L, Levın O, Nord CE, et al. (1986) Influence of frying fat on mutagenic activity in lean pork meat. Mutat Res 171: 115-121. 